\title{
気体プラズマの $\mathrm{A} \cdot \mathrm{K} \cdot \mathrm{C} ・ \mathrm{R} \cdot$ 㳊関する \\ コメント II (補足 )
}

北尾一夫

( 48 年 4 月 12 日受理 )

（新潟大理）

先のコメントでは, ${ }^{1} ）$ 波のエネルギーのプラズマによる吸収の有無につけての議論が目的であへ たので,エネルギーのやりとりの観点からのみ考察した。そのため，一部に不正確な所があるので補 足したい。

先のコメントで，正常波に関する分散式を実数の $\mathrm{k}$ に対して $\omega$ につんて解くと， $\omega^{2}$ は実数，従っ ていは実数または純虚数になると述べた。プラズマによるエネルギー吸収のないとととての結果は矛

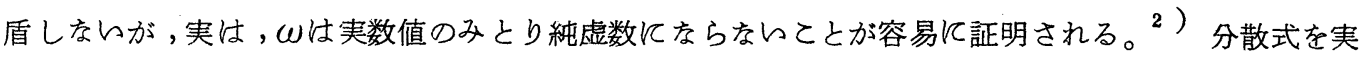

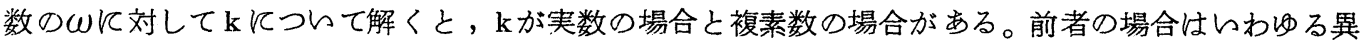
常伝播の場合で, 後者の場合が論文 M T の議論の対象になった。後者のように，実数 $\mathrm{k}$ に対して実根 $\omega か ゙$ 得られ，実数 $\omega$ に対して複素根 $\mathrm{k}$ が得られる場合は，波束に基づく考祭によれば， ${ }^{3}$ ）上く知ら れているょうと波の evanescence を表わす。即ち，半無限プラズマの外加正常波を入射すると， 反射されるだけ（反射率＝1）である。

分散式を满足する単色波を重ねて波束を合成できるかどうかによって，例えば，波の增巾か evanescence かを判断するのが普通であるが，乙の方法ではェネルギーのやりとりとつんては情報が 得られない。他方, 筆者のよらなエネルギーのやりとりからの考察では, 伝播か反射かの判定が困難 のようである。この点についての詳しい考察については後日にめずりたい。

コメントの主題から少し外れたが，先のコメントに疑問をるたれる方すあるかと思われるので，以 上の補足を加えた。 
1) K. Kitao: Kakuyugo-Kenkyu 29, 70 (1973).

2) D. E. Baldwin et al.: Advances in Plasma Physics Vol. 3 (eds. Simon and Thompson, Interscience, 1969) p.l.

3) P. Sturrock: Phys. Rev. 112, 1488 (1958).

A. I. Akhiezer et al.: Kollektivnye Kolebanya v Plazme (Atomizdat, Moscow, 1964) Chap. 3.

P. C. Clemmow and J. P. Dougherty: Electrodynamics of Particles and Plasmas (Addison-Wesley, 1969) Chap. 6. R. J. Griggs: Electron-Stream Interaction with Plasmas (M.I.T. Press, 1964). 